\begin{tabular}{cc|c|c|c|c|}
\hline Bentham open & The Open Biomedical Engineering & $\begin{array}{l}\text { The } \\
\text { Biomedical } \\
\text { Engineering } \\
\text { lournal }\end{array}$ \\
\hline CrossMark & Content list available at: www.benthamopen.com/TOBEJ/ & DOI: $10.2174 / 1874120701610010111$ \\
\hline
\end{tabular}

\title{
RETRACTION
}

\section{Retraction Notice: Preparation and Antioxidant Activity of Purple Potato Wine}

Liu Zhong-hua ${ }^{*}$ and Guo Jie

College of Life Science and Agronomy, Zhoukou Normal University, Zhoukou, Henan, 466000, China

\section{RETRACTION}

The Publisher and Editor have retracted this article [1] in accordance with good ethical practices. After a thorough investigations we believe that the peer review process was compromised. The article was published on-line on 09-10-2015.

\section{REFERENCES}

[1] L. Zhong-hua, and G. Jie, "Preparation and antioxidant activity of purple potato wine", Open Biomed. Eng. J., vol. 9, pp. 282-287, 2015.

(C) Zhong-hua and Jie; Licensee Bentham Open.

This is an open access article licensed under the terms of the Creative Commons Attribution-Non-Commercial 4.0 International Public License (CC BY-NC 4.0) (https://creativecommons.org/licenses/by-nc/4.0/legalcode), which permits unrestricted, non-commercial use, distribution and reproduction in any medium, provided the work is properly cited.

\footnotetext{
* Address correspondence to this author at the College of Life Science and Agronomy, Zhoukou Normal University, Zhoukou, Henan, 466000,
} China; Tel: 13839439312; E-mail: 1zh.hzl@163.com 